\title{
THE USE OF FORAMINIFERA FOSSILS FOR RECONSTRUCTING THE YOGYAKARTA GRABEN, YOGYAKARTA, INDONESIA
}

\author{
Didit Hadi Barianto ${ }^{* 1}$, Pentatok Kuncoro ${ }^{1}$, and Koichiro Watanabe ${ }^{2}$ \\ ${ }^{1}$ Department of Geological Engineering, Faculty of Engineering, Universitas Gadjah Mada, Indonesia \\ ${ }^{2}$ Department of Earth Resource Engineering, Faculty of Engineering, Kyushu University, Japan
}

\begin{abstract}
The Yogyakarta region is located in the southeastern part of Central Java, Indonesia. The region forms an elongated northeast-southwest-trending central depression bordered by two parallel faults in the west and east. These major faults divided the area into three parts, including the western, central and eastern parts. Herein, we investigate the relative uplift rate of the each part by using planktonic and benthonic foraminiferas. The foraminifera will show the initial position/datum of each part before uplift. Over sixty samples (primarily limestones and marls) were taken for this research. The uplift rates of each part were different and created a depressed block control by way of parallel faults. Based on foraminifera fossil observations, each block was in the same depositional environment (inner neritic) during N9. The present positions indicate that the western part was uplifted higher than the others, with this part being uplifted more than 590 meters. The central part was uplifted less than 120 meters, and the eastern part was uplifted above an altitude of 170-300 meters.
\end{abstract}

Keywords: Foraminifera fossil, planktonic, benthonic, graben, uplift.

\section{Introduction}

The Yogyakarta region is located in the southeastern part of Central Java, Indonesia. The region forms an elongated northeast-southwest-

\footnotetext{
${ }^{*}$ Corresponding author: DIDIT H. BARIANTO, Department of Geological Engineering, Faculty of Engineering, Universitas Gadjah Mada, Jl. Grafika 2, Yogyakarta 55281. E-mail: didit_geologi@ugm.ac.id
}

trending central depression bordered by several tertiary volcanic and carbonate massifs, including (i) the West Progo Mountains to the west (western part), (ii) the Gunung Kidul Mountains to the east (eastern part), (iii) an active Merapi volcano to the north, and (iv) the Indian Ocean to the south. This area is physiographically known as graben (MacDonald et al., 1984), all published geologic maps show primarily an eastern normal fault as the border between the central depression and the mountainous zone of the eastern part (Rahardjo et al., 1996) and Sudarno, 1996) while in the western part, the location of the fault was describe by Barianto et al. (2009). Figure 1 show the distribution of fault from previous studies.

All data sets were converted into GIScompatible formats. We employed Landsat TM 1995, compiled with height points from topographic maps of Yogyakarta, Indonesia published by BAKOSURTANAL (National Coordinating Agency for Surveys and Mapping, 2001) with a scale of 1: 25,000 for creating 3D images. Foraminifera were collected at the Jonggrangan Formation, Sentolo Formation, Oyo Formation, Wonosari Formation, and Kepek Formation. All observations were conducted at the Laboratory of Paleontology, Gadjah Mada University, Indonesia. A total of 60 samples were examined in order to identify planktonic and bentonic foraminifera to determine the age and depositional environment of the studied area. Fossil observations were 


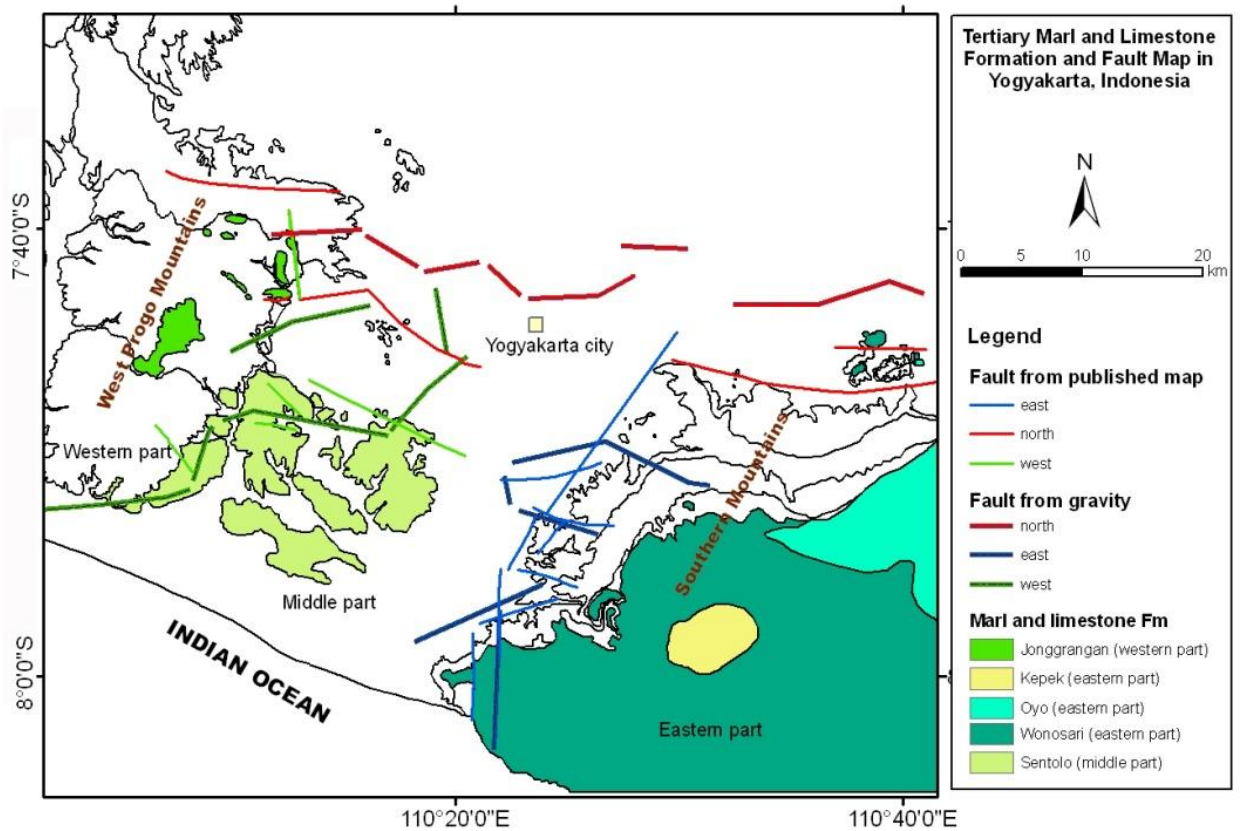

Figure 1: This map shows the fault control development of Yogyakarta graben and distribution of marls and limestone in the research area. The fault was determined based on satellite and gravity data interpretation and fault map data from previous studies (Rahardjo et al., 1977, Mac Donald and Partners, 1984, Sudarno, 1997 and Barianto et al., 2009) while the marls and limestone distribution was determined based on satellite interpretation.

identified according to Barker (1960) and Bolli and Saunders (1985).

The uplift rates of each part are different, and based on data from foraminifera fossil observations, each part was at the same level of environmental deposition (inner neritic/ shallow marine) during N9 (about 14.8-15.1 Ma; Berggren et al., 1995). Currently, the western part is located at an altitude of $590 \mathrm{~m}$ above msl (mean sea level), the central part is located at an altitude of less than $120 \mathrm{~m}$ above msl, and the Oyo and the eastern part is located above an altitude of 170-300 $\mathrm{m}$ above msl. These differences indicate the existence of geological structural boundaries in the form of faults that have different uplifts rates.

\section{The Geological Setting}

The West Progo Mountains and the Gunung Kidul Mountains are moderately rugged mountainous areas located in the western and eastern parts of the Yogyakarta region, respectively, and are considered as a western block and an eastern block. A geologic map of Yogyakarta is shown in Figure 2. Based on reports from Rahadjo et al. (1977), the tertiary rocks unconformably rest upon a metamorphic pre-tertiary basement (unit 1). The earliest tertiary rocks are Eocene shallow marine sedimentary rocks that are found as small scattered outcrops at both the Gunung Kidul Mountains (known as the Gamping-Wungkal Formation (unit 2b)) and Kulon Progo Mountains (known as the Nanggulan Formation (unit 2a)). Arc volcanism has been active since the late Oligocene, and most rocks deposited after this period consist some amount of volcanic material. The sediments are overlain by a thick succession of marine volcanics, which represent the late Paleogene volcanic arc (25.4-29.6 Ma; Soeria-Atmadjaja et al., 1994) (known as the Gadjah Formation (unit 3b)). This arc followed an east-west direction, similar to formations found in the western and eastern parts of the region, including the Kebobutak Formation (unit 3a), and the southern part of Nglanggran (unit 3c), includ- 


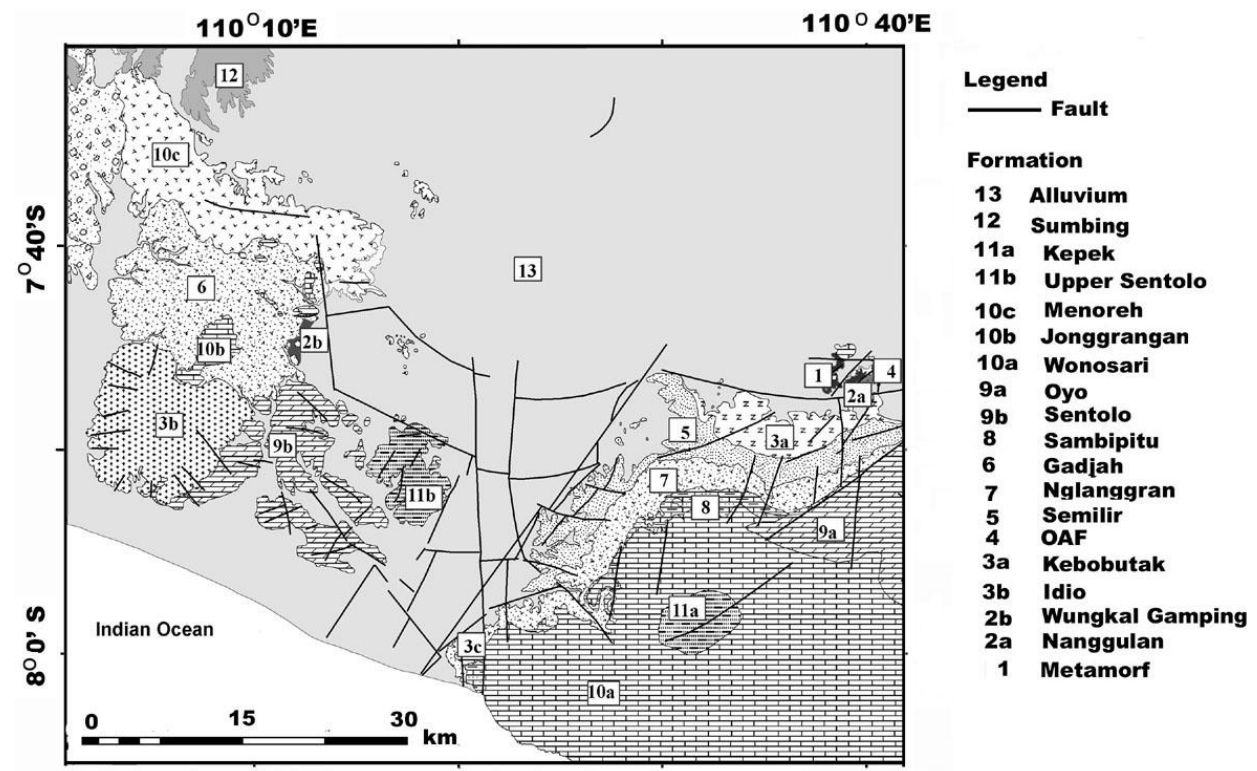

Figure 2: Geologic Map of Yogyakarta based on Geologic Map 1:100,000 (Rahardjo et al.,1976), interpretation Landsat TM 1995 and ETM 2001, Topographic Map 1:25,000 (BAKOSURTANAL, 2001). Fault data was compiled from Rahardjo (1977), Mac Donald and Partners (1984), Sudarno (1997) and Barianto et al. (2009).

ing the Parangtritis Formation (26.4 and 26.55 Ma; Soeria-Atmadja et al., 1994).

These rocks are intruded by a diorite-gabro (unit 4), which then covered volcanic sediments by the early to middle Miocene, namely the Semilir Formation (unit 5), Nglanggran Formation, and Sambiputu Formation (unit 7-8). These rocks are cropped out on the eastern side of the Opak River to form a steep cliff. In the western part, the andesite body was intruded by the Idjo Formation (unit 6) during the Middle Miocene (17.0 \pm 2.0 to $16.0 \pm 2.2$ Ma by SoeriaAtmadja et al., 1994).

Volcanic sediment is covered by mixed volcanic and carbonate sediment, known as the Sentolo Formation (unit 9b) in western part and the Oyo Formation in eastern part (unit 9a), during the early to late Miocene. Bioturbation, such as animal/worm tracks and trails, have been found in this formation. While the depositional environment of the formations is interpreted to have a deep marine influence, this interpretation remains under debate. In the shallow area, reef growth developed into a carbonate series of the Jonggrangan Formation (unit 10b) in the west and the Wonosari For- mation in the east (unit 10a) during the middle to late Miocene. The volcanic region north of Jonggrangan, known as the Menoreh Formation (unit 10c), developed during the upper Miocene $(11.4 \pm 0.7$ and $12.4 \pm 0.7 \mathrm{Ma}$; Setijadji, 2005).

The Kepek Formation (unit 11a), located in the Gunung Kidul Mountains, was deposited during the late Miocene to Pliocene, which is similar to the upper part of the Sentolo Formation in the west (unit 11b). This formation consists of bedded marls and limestones, which are rich in small foraminifera. In some areas, the Kepek Formation passed laterally into the limestone faces of the Wonosari Formation. The volcanic arc then moved to the north during the Pliocene and deposited volcanic rocks and sediment (unit 12) (Setijadji, 2005).

All of these formations are unconformably covered by quaternary fluvio-volcanic products of the Merapi and are associated with alluvial deposits (unit 13). The age of the formations is important in order to investigate tectonic evolution by use of lineament maps. All surface expressions are controlled by faults and joints, which occurred after the formation was created. 
Four sets of structural trends in the Gunung Kidul Mountains were recognized by Sudarno (1997). They include: (i) the first trend, which is an NE-SW sinistral fault due to N-S compressional stress that was induced by the subduction of Indo-Australian plate during the late Eocene to late-to-middle Miocene; (ii) the second trend is an N-S, and mostly comprised of sinistral faults, except for normal faults at Parangtritis at the western border of the Southern Mountain; (iii) the third trend, which is the NW-SE dextral fault, is the result of the NNW-SSE compressional stress that was developed during the late Pliocene; (iv) the fourth trend, is an E-W, and comprised primarily of normal faults due to an approximate N-S extensional stress during the early Pliocene. This extensional stress has reactivated some preexisted faults into normal faulting.

\section{Data Processing}

Over sixty samples (primarily limestones and marls) were taken from different locations of four formations, including the Sentolo, Wonosari, Oyo, and Kepek. Cementing material in the samples was removed using water and peroxides. The particles were observed under a binocular microscope with magnifications of $10-100 \times$.

The primary objects of observation were the planktonic and benthonic foraminifera fossils. With reference to Barker (1960), Blow (1969), and Bolli and Sanders (1985), foraminifera fossils can be used to determine the time and environment of sedimentation. Samples used for paleontology analysis were taken from several formations, including the Jonggrangan Formation (in the western part), the Sentolo Formation (in the central part), and the Oyo and Wonosari Formations (in the eastern part). In general, the carbonated sediment in this area was sedimented during the middle Miocene through the upper Miocene, with depositional environments between the inner neritic and the outer neritic.

During the middle Miocene (N9), there is a similarity in the sedimentation environments of the four formations. The existence of the planktonic foraminifera such as Globigerinoides diminutus, Globigerinoides sicanus, and Orbulina universa indicate the middle Miocene or N9 (Bolli and Sanders, 1985). The existence of the foraminifera bentonic such as Elphidium advenum, Triloculina sp, and Amphistegina lessonii indicate the existence of inner neritic environment (Barker, 1960). The four formations are currently spread on different height levels, whereby the middle part is in the lowest position (as shown in Table 11). This also shows the possibility of the existence of two faults that bordered the middle part as a normal fault.

In order to predict the uplift time, we observe the fossils of the youngest marine sediments. The youngest marine sediments were found at the top of the mountains, and includes the Kepek Formation and Sentolo Formation. These formations were sedimented during the Pliocene in the outer neritic-upper bathial (100-200 m below sea level). This indicates that up to the Pliocene, the sedimentation environment becomes deeper. We assume that the uplifting process occur after the Pliocene.

\section{Discussion and Conclusion}

Sudarno (1996) explained that Yogyakarta region had two tectonic compression phases which caused uplift and transform fault, and one extension phase which caused graben and normal fault. Based on the foraminífera fossil analysis, up to early Pliocene the rock which formed Kepek formation still formed until $100 \mathrm{~m}$ below sea level. These indicated that uplifted process started at early Pliocene.

During the middle Miocene (N9), there was similarity in the sedimentation environments (inner neritic) of the four formations that currently have different elevations (Jonggrangan Formation, i.e., $550 \mathrm{~m}$ above msl, Sentolo Formation, i.e., less than $120 \mathrm{~m}$ above msl Oyo Formation and Wonosari Formation, i.e., 170-350 $\mathrm{m}$ above $\mathrm{msl}$ ). These differences show the existence of geological structural boundaries in the form of faults that have different uplifts, of which the western block is the highest. They also indicate that the dominant process that has occurred in this area is uplift, rather than the 
movement of the normal fault. Meanwhile, the tops of the eastern part (Kepek Formation) and the central part (Sentolo Formation) were sedimented at the outer neritic-upper bathial (100-200 m below sea level) during the early Pliocene. Based on this evidence, a major uplift occurred after both formations were created.

Western block lifted up higher than Eastern block. This process indicated that uplifts in Yogyakarta region have not occured in the same time. Middle block assumed lifted up higher than Eastern block, however in the extension phase the Middle block was subside which changed sinistral faults to the normal faults. These processes made the Yogyakarta Graben. The uplifted average of the Western block is $0.01 \mathrm{~cm} /$ years whereas Eastern block is $0.005 \mathrm{~cm} /$ years.

\section{References}

BAKOSURTANAL, Topographic Map Yogyakarta sheet number 1407-1408 (30 sheets), Bakorsurtanal, Bandung, 2001.

Barker, R.W., Taxonomic Notes - on the Species Figured by H. B. Brady in His Report on the Foraminifera Dredged by H.M.S. Challenger during the Years 1873-1876, Society of Economic Paleontologists and Mineralogists, Special Publication No. 9, 238 p, Tulsa, Oklahoma, 1960.

Barianto, DH; Aboud, Essam; Setijadji, L D; Watanabe, Koichiro., Structural Analysis using Landsat TM, Gravity Data, and Paleontological Data from Tertiary Rocks in Yogyakarta, Indonesia , Kyudai Memoars, Fukuoka, 2009.
Berggren, W.A., Kent, D.V., Swisher III, C.C., Aubry, M.P., A Revised Cenozoic geochronology and chronostratigraphy. In: Berggren, W.A., et al. (Eds.), Geocronology, Time Scales and Gleology. Society of Economic Paleontologist and Mineralogist, Special Publication 54, pp. 129-212, 1995.

Blow, W.H., Late Middle Eocen to Recent Planktonic Foraminiferal Biostratigraphy, Bronnimann, P. and Renz, H.H. eds., Proceedings of The First International Conference on Planktonic Microfossil, Geneva 1967, Leiden, E.J. Brill. Vol. I, 1969.

Blow, W.H., The Cainozoic Globigerinida, Part I and Part II, Section I, 752 p, Leiden E. J. Brill, New York, 1979.

Bolli H.M., and Saunders, J.B., Planktonic Stratigraphy, 599 p, Cambridge University Press, Cambridge, 1985.

Rahardjo, W., Sukandarrumidi, and Rosidi, H.M.D., Geological map of the Jogjakarta Sheet, Jawa. Geological Research and Development Centre, Bandung, 1977.

Rahardjo, W., Sukandarrumidi, and Rosidi, H.M.D., Geological map of the Jogjakarta Sheet, Jawa. 2nd edition, Geological Research and Development Centre, Bandung, 1996.

Sir Mac Donald \& Partners (MMP), Greater Yogyakarta groundwater resources study: Volume 3. Groundwater. Technical report for the Directorate General of Water Resources Development Groundwater Development Project, 116 p.

Sudarno, Ign., Kendali tektonik terhadap pembentukan struktur pada batuan Paleogen dan Neogen di Pegunungan Selatan, Daerah Istimewa Yogyakarta dan sekitarnya. Master Thesis at Bandung Institute of Technology (in Indonesian), 1997. 


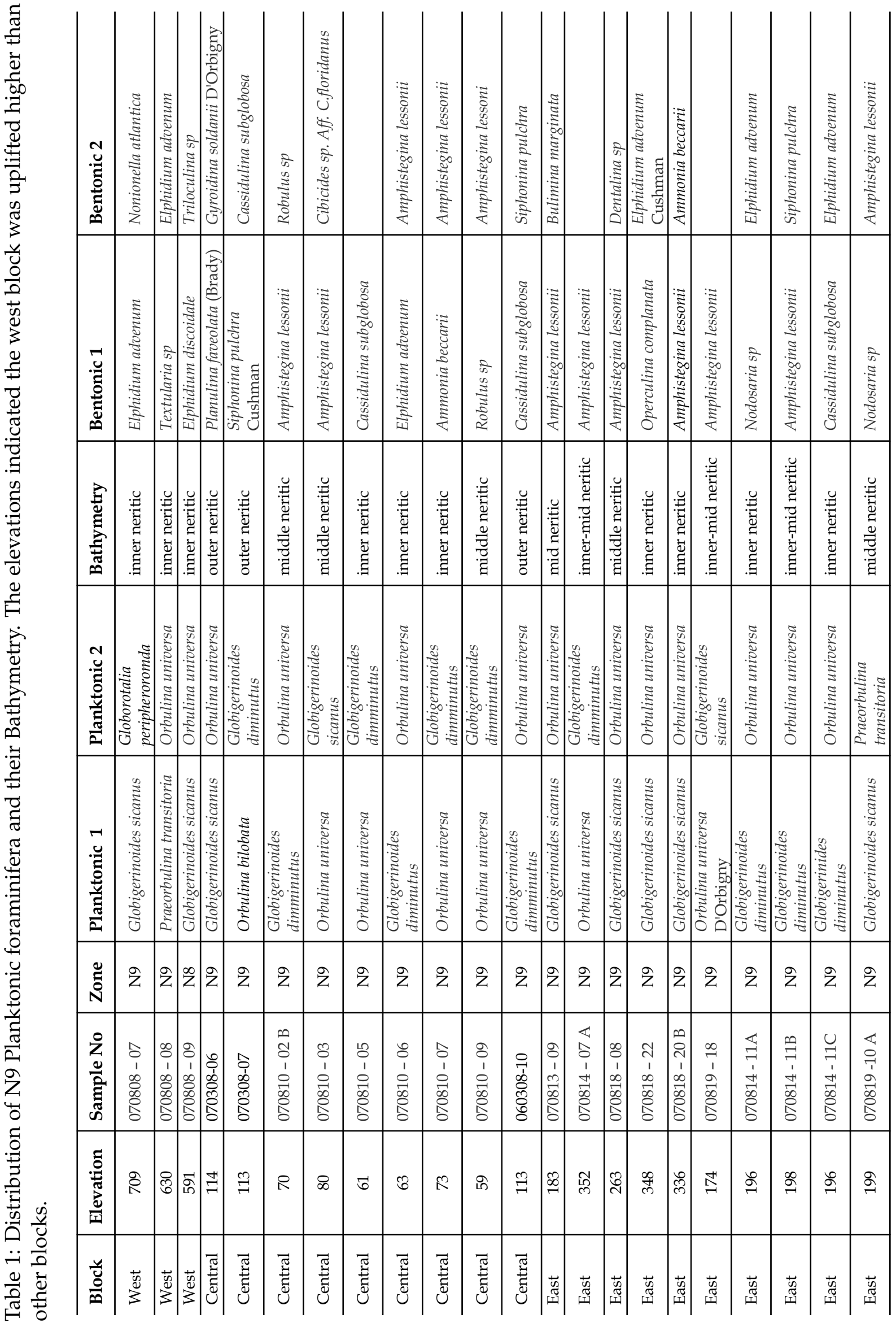

